\title{
Bacteriological and physicochemical quality of treated wastewater of the Mzar treatment plant
}

\author{
M. Bourouache ${ }^{1} \cdot$ R. Mimouni ${ }^{1} \cdot$ A. Ait Alla ${ }^{1} \cdot$ F. Hamadi ${ }^{1} \cdot$ A. El Boulani ${ }^{1} \cdot$ B. Bihadassen ${ }^{1}$
}

Received: 19 February 2018 / Accepted: 16 April 2019 / Published online: 9 May 2019

(c) The Author(s) 2019

\begin{abstract}
In order to use purified wastewater on watering green spaces of Agadir city, we conducted this study to assess the bacteriological and physicochemical quality of treated wastewater in Mzar treatment plant. To realize these objectives, we analyzed four types of waters: raw water (RW), decanted water, purified water and purified water treated by the ultraviolet radiation (PWUV). The biologically analyzed parameters are fecal coliforms (FC) and fecal enterococci (FE). The physicochemical parameters are: $\mathrm{pH}$, electrical conductivity, chemical oxygen demand (COD), five-day biological oxygen demand $\left(\mathrm{BOD}_{5}\right)$ and total suspended solids (TSS). The results showed a high level of bacterial contamination in all types of waters, and the average loads of FC were between $4.71 \times 10^{6} \mathrm{CFU} / 100 \mathrm{~mL}(\mathrm{RW})$ and $1.45 \times 10^{3} \mathrm{CFU} / 100 \mathrm{~mL}$ (PWUV), while loads of FE were between $2.62 \times 10^{5} \mathrm{CFU} / 100 \mathrm{~mL}$ (RW) and $7.92 \mathrm{CFU} / 100 \mathrm{~mL}$ (PWUV). The physicochemical parameters show a $\mathrm{pH}$ close to neutrality and a high electrical conductivity $(3261 \mu \mathrm{S} / \mathrm{cm})$ in PWUV. In all stages of wastewater treatment, values of $\mathrm{COD}, \mathrm{BOD}_{5}$ and TSS were under the limit values recommended by Moroccan standards. Except for the electrical conductivity and FC, all the studied parameters were under the limit values requested by the Moroccan standards. The microbiological quality of PWUV is unstable, and if these waters are reused, they can affect the microbiological and physicochemical quality of green spaces and groundwater.
\end{abstract}

Keywords Morocco $\cdot$ Wastewater · Green spaces $\cdot$ Physicochemical parameters $\cdot$ Thermotolerant coliforms $\cdot$ Fecal enterococci

\section{Introduction}

Like most local countries, Morocco suffers from scarcity and unequal distribution of water. In this context, alternative sources of water would be greatly appreciated (Ouhamdouch et al. 2016). Indeed, the water deficit can be filled mainly by treated wastewater; this resource is abundantly and continuously available. It has many advantages, notably a reasonable cost compared to the desalinating seawater or digging wells. (The water table is too deep in the Souss Massa region.) These waters are naturally rich in phosphates and nitrates that allow the minimization of industrial fertilizers needs.

R. Mimouni

r_mimouni@yahoo.fr

1 Laboratory of Microbial Biotechnology and Plant Protection, Faculty of Sciences of Agadir, Ibn Zohr University, P.O. Box 8106, Agadir, Morocco
Reusing treated wastewater has very important environmental aspects. In reality, once treated it protects receiving environments: lakes, rivers, estuaries and oceans. Despite the benefits of wastewater reuse, it could presents significant risks for users and the environment (eutrophication and heavy metals) (Habbari et al. 2000; Metcalf and Eddy 2003; Cha et al. 2004; Qadir et al. 2010; Fatta-kassinos et al. 2011). Actually, household sewage contains a high percentage of organic materials and pathogenic microorganisms, including bacteria, viruses and parasites. Many diseases are associated with such microorganisms including typhoid, dysentery, diarrhea, vomiting and malabsorption. Any human contact with the raw wastewater might be hazardous (Shakir et al. 2017). In Morocco, many studies have focused on this point. Sadly, just few studies have been carried out in Agadir (Mimouni et al. 2002, 2003; Alla et al. 2006; Eddabra et al. 2011), which is particularly characterized by an arid climate, and high industrial and agricultural activities. Many of the reported studies in Agadir were focalized on chemical risks (Mouhanni et al. 2011; 
Aba-aaki et al. 2013) and microbiological hazards of reuse of wastewater (Touyer et al. 1998; Mimouni et al. 2002, 2003; Eddaoudi et al. 2004; Eddabra 2011; Fonteneau et al. 2017). The purpose of this study is to evaluate the possibility of reusing treated wastewater from the Mzar treatment plant in the irrigation of green spaces. It mainly consists in studying different parameters (i.e., thermotolerant coliforms, fecal enterococcus, temperature, $\mathrm{pH}$, electrical conductivity, $\mathrm{COD}, \mathrm{BOD}_{5}$ and TSS), which govern the reuse of wastewater and compare it with national and international standards.

\section{Materials and methods}

\section{Description of Mzar treatment plant}

The Mzar treatment plant $\left(30^{\circ} 20^{\prime} 28.1^{\prime \prime} \mathrm{N}, 9^{\circ} 35^{\prime} 35.0^{\prime \prime} \mathrm{W}\right)$ is located in the south of Agadir, Morocco; it was built in
2002 inside the Souss Massa national park (Fig. 1). The purification mode, includes three successive treatment stages (Table 1), carried out as follows: a first stage in which the raw water is sedimented for 3 days in the settling basins, with a treatment capacity of $75,000 \mathrm{~m}^{3} /$ day; a second treatment stage, in which decanted water is percolated in the sand basins, which provides a treatment capacity of $30,000 \mathrm{~m}^{3} /$ day; and the third stage, which allows a treatment capacity of $30,000 \mathrm{~m}^{3} /$ day. Finally, the infiltrated water is disinfected by UV exposure (RAMSA 2002).

\section{Samples collection}

A total of 60 samples were collected over 5 months; the sampling lasted from February to June 2015. Monthly, three replicates of each sample were collected from four sampling points (Fig. 1). It included: raw water (RW) at entrance to the plant, decanted water (DW) after three sedimenting days

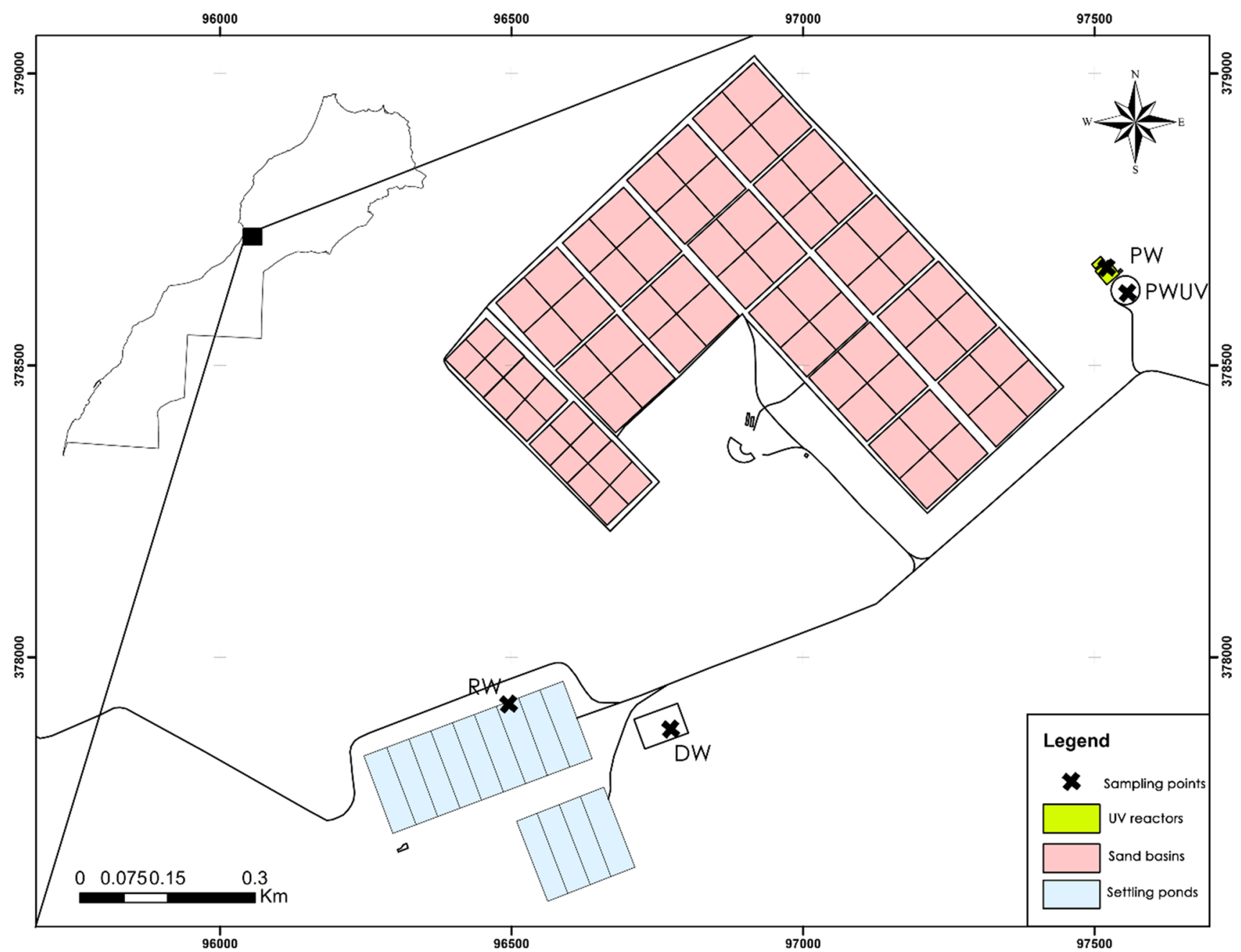

Fig. 1 Map of the Mzar wastewater treatment plant, located in the south of Agadir, Morocco. $R W$ raw water, $D W$ decanted water, $P W$ purified water, $P W U V$ purified water disinfected with ultraviolet radiation 
Table 1 Physical and geometrical characteristics of the wastewater treatment process of the Mzar WWTP Source: RAMSA (2002)

\begin{tabular}{|c|c|c|c|c|c|c|}
\hline \multicolumn{2}{|c|}{ Primary treatment: anaerobic decantation } & \multicolumn{2}{|c|}{$\begin{array}{l}\text { Secondary treatment: infiltration } \\
\text { percolation }\end{array}$} & \multicolumn{3}{|c|}{ Tertiary treatment: UV disinfection } \\
\hline Flow & $75,000 \mathrm{~m}^{3}$ per day & Flow & $10,000 \mathrm{~m}^{3}$ per day & Flow & & $30,000 \mathrm{~m}^{3}$ per day \\
\hline Number of decanters & 13 & Number of filters & 64 & $\begin{array}{l}\text { Pumps (nu } \\
\text { ity) }\end{array}$ & er and unit capac- & $6+1$ Pumps $-270 \mathrm{~m}^{3} / \mathrm{h}$ \\
\hline Length of decanter & $115 \mathrm{~m}$ & Filter surface & $5000 \mathrm{~m}^{2}$ & $\begin{array}{l}\text { Reactors ( } \\
\text { ity) }\end{array}$ & nber and unit capac- & $\begin{array}{l}6 \text { Reactors- }-5000 \mathrm{~m}^{3} \\
\text { per day }\end{array}$ \\
\hline Width of decanter & $35 \mathrm{~m}$ & Sand thickness & $2 \mathrm{~m}$ & UV lamps & Number per reactor & 14 lamps \\
\hline $\begin{array}{l}\text { Depth of the decanter } \\
\text { at the deposit area }\end{array}$ & $6.59 \mathrm{~m}$ & Gravel thickness & $0.5 \mathrm{~m}$ & & Wavelength & $254 \mathrm{~nm}$ \\
\hline $\begin{array}{l}\text { Depth of decanter at } \\
\text { lagoon area }\end{array}$ & $4.24 \mathrm{~m}$ & Infiltration speed & $1 \mathrm{~m}$ per day & & Exposure dose & $50 \mathrm{~mJ} / \mathrm{cm}^{2}$ \\
\hline $\begin{array}{l}\text { Total volume of } \\
\text { decanter }\end{array}$ & $210,000 \mathrm{~m}^{3}$ & $\begin{array}{l}\text { Filter bottom } \\
\text { sealing material }\end{array}$ & $\begin{array}{l}1 \text { mm thick of } \\
\text { HDPE geomem- } \\
\text { brane }\end{array}$ & & $\begin{array}{l}\text { Service life } \\
\text { Contact time }\end{array}$ & $\begin{array}{l}16,000 \mathrm{~h} \\
4 \mathrm{~s}\end{array}$ \\
\hline
\end{tabular}

in the settling ponds, and purified water (PW) at the output of the sand basins, finely, purified water disinfected with ultraviolet radiation (PWUV) at the exit of the UV reactors.

\section{Bacteriological and physicochemical analyses}

Samples were taken in strict aseptic techniques to prevent any accidental contamination. Each sample was carried out in sterile flasks. Collected samples were stored in a cooler $\left(4{ }^{\circ} \mathrm{C}\right)$ and then transmitted to the laboratory on the same day for analysis. They were analyzed by filtration method (100 $\mathrm{mL}$ on $0.45 \mu \mathrm{m}$ membrane), according to the standards of ISO 9308-1:2014. Results were expressed by colony forming units (CFU) per $100 \mathrm{~mL}$ of sample.

The $\mathrm{pH}$, temperature, conductivity and COD were determined in situ by a $\mathrm{pH}$ meter equipped with a multi-parameter probe types CONSORT C831. The total suspended solids (TSS) were identified by filtration (Whatman circular filters of $47 \mathrm{~mm}$ in diameter and $0.45 \mu \mathrm{m}$ of porosity), according to French Standard Methods AFNOR 2005 (T90-105). The five-day biological oxygen demand $\left(\mathrm{BOD}_{5}\right)$ was determined by the manometric method with a respirometer (types WTW), according to AFNOR standard (NF T90101). The oxidizable matter (OM) is calculated as follows: Oxidizable matters $=(2 \mathrm{BOD} 5+\mathrm{COD}) / 3 \mathrm{mg} / \mathrm{L}$.

\section{Results}

\section{Physicochemical parameters}

The $\mathrm{pH}$ values were semi-neutral in all types of waters (Table 2). The temperature averages ranged between $19.1^{\circ} \mathrm{C}$ and $20.9{ }^{\circ} \mathrm{C}$. The conductivity variations were important (2170-3340 $\mu \mathrm{S} / \mathrm{cm})$, the lowest recorded value was the one of RW and the most important was the one of PW (Table 2). For PW and PWUV, values recorded for conductivity are all higher than $3000 \mu \mathrm{S} / \mathrm{cm}$, which is the limit value of direct discharge into the receiving environment. The extreme values of $\mathrm{BOD}_{5}$ were, respectively, $1720 \mathrm{mgO}_{2} / \mathrm{L}$ and $11 \mathrm{mgO}_{2} / \mathrm{L}$, recorded upstream and downstream the Mzar WWTP (Table 2).

The COD recorded values for the PW remain below $500 \mathrm{mgO}_{2} / \mathrm{L}$. Upstream and downstream the plant, the average values are, respectively, $1821 \pm 280 \mathrm{mgO}_{2} / \mathrm{L}$ and $43 \pm 7 \mathrm{mgO}_{2} / \mathrm{L}$ (Table 2). For total suspended solids as for $\mathrm{BOD}_{5}$ and $\mathrm{COD}$, the values at the entry of the station are very important, and then, after the process, these values decrease until they reach the lowest values in PW and PWUV (Table 2).

\section{Typology of Agadir's waters}

Assessing the ability of wastewater to biodegrade is of primary interest for wastewater treatment. Indeed, this biodegradation ability will guide the choice of treatment process (biological or physicochemical treatment). The combination of the two global pollution parameters COD and $\mathrm{BOD}_{5}$ allows a good approach to biodegradability, the COD representing the organic matter as a whole and the BOD the only biodegradable fraction under fixed conditions (Rodier et al. 2009). The relationship between COD, $\mathrm{DBO}_{5}$ and TSS allows the estimation of the oxidizable matter (OM) and has a very important interest for a better appreciation of the origins, nature and biodegradability of the studied effluents (Table 3). 
Table 2 The average values of physicochemical parameters of Agadir wastewater, from February to June 2015

\begin{tabular}{|c|c|c|c|c|c|c|}
\hline Parameters & Unit & Water type & Minimum & Maximum & Average $n=5$ & SD \\
\hline \multirow[t]{4}{*}{$\mathrm{pH}$} & \multirow[t]{4}{*}{-} & RW & 7.40 & 7.67 & 7.54 & 0.12 \\
\hline & & DW & 7.31 & 7.42 & 7.37 & 0.06 \\
\hline & & PW & 7.85 & 8.00 & 7.92 & 0.07 \\
\hline & & PWUV & 7.93 & 7.99 & 7.95 & 0.03 \\
\hline \multirow[t]{4}{*}{ Temperature } & \multirow[t]{4}{*}{${ }^{\circ} \mathrm{C}$} & RW & 19.50 & 20.90 & 20.15 & 0.57 \\
\hline & & DW & 19.30 & 20.40 & 19.75 & 0.54 \\
\hline & & PW & 19.10 & 19.50 & 19.23 & 0.19 \\
\hline & & PWUV & 19.20 & 19.80 & 19.53 & 0.32 \\
\hline \multirow[t]{4}{*}{ Electrical conductivity } & \multirow[t]{4}{*}{$\mu \mathrm{S} \mathrm{cm}-1$} & RW & 2170.00 & 3010.00 & 2520.00 & 352.42 \\
\hline & & DW & 2780.00 & 3110.00 & 3002.50 & 155.64 \\
\hline & & PW & 3240.00 & 3340.00 & 3302.50 & 45.00 \\
\hline & & PWUV & 3120.00 & 3314.00 & 3261.50 & 94.47 \\
\hline \multirow[t]{4}{*}{ COD } & \multirow[t]{4}{*}{$\mathrm{mgO}_{2} \mathrm{~L}^{-1}$} & RW & 1412.00 & 2045.00 & 1821.50 & 280.06 \\
\hline & & DW & 528.00 & 834.00 & 716.75 & 133.90 \\
\hline & & PW & 36.00 & 56.00 & 44.50 & 7.55 \\
\hline & & PWUV & 34.00 & 57.00 & 43.00 & 7.79 \\
\hline \multirow[t]{4}{*}{$\mathrm{BOD}_{5}$} & \multirow[t]{4}{*}{$\mathrm{mgO}_{2} \mathrm{~L}^{-1}$} & RW & 983.78 & 1720.14 & 1389.44 & 313.17 \\
\hline & & DW & 321.00 & 422.25 & 385.16 & 44.89 \\
\hline & & PW & 7.00 & 20.15 & 11.52 & 5.84 \\
\hline & & PWUV & 7.00 & 22.04 & 11.34 & 5.48 \\
\hline \multirow[t]{4}{*}{ TSS } & \multirow[t]{4}{*}{$\mathrm{mg} \mathrm{L}^{-1}$} & RW & 593.00 & 785.00 & 697.81 & 81.51 \\
\hline & & DW & 245.00 & 420.00 & 321.98 & 86.78 \\
\hline & & PW & 4.00 & 11.00 & 6.84 & 3.03 \\
\hline & & PWUV & 4.00 & 11.00 & 6.50 & 3.11 \\
\hline
\end{tabular}

$R W$ raw water, $D W$ decanted water, $P W$ purified water, $P W U V$ purified water treated by the ultraviolet radiation, $p H$ power of hydrogen ion, $E C$ electrical conductivity, $C D O$ chemical oxygen demand, $B O D_{5}$ biochemical oxygen demand after 5 days, TSS total suspended substance

Table 3 Oxidizable matter and biodegradability of Mzar sewage effluent

\begin{tabular}{lccrrrrrrr}
\hline Parameters studied & February 2015 & March 2015 & April 2015 & May 2015 & June 2015 & Min & Max & Average $n=5$ & SD \\
\hline $\mathrm{COD}_{\mathrm{BOOD}}$ & 1.45 & 1.35 & 1.44 & 1.11 & 1.37 & 1.11 & 1.45 & 1.34 & 0.14 \\
$\mathrm{BOD}_{5} / \mathrm{COD}$ & 0.69 & 0.74 & 0.70 & 0.90 & 0.73 & 0.69 & 0.90 & 0.75 & 0.09 \\
$\mathrm{TSS} / \mathrm{BOD}_{5}$ & 0.51 & 0.52 & 0.60 & 0.42 & 0.49 & 0.42 & 0.60 & 0.51 & 0.06 \\
$\mathrm{OM}(\mathrm{mg} / \mathrm{L})$ & 1531.60 & 1695.30 & 1126.50 & 1780.40 & 1597.30 & 1126.50 & 1780.40 & 1546.20 & 253.00 \\
\hline
\end{tabular}

\section{The COD/BOD 5 ratio}

The $\mathrm{COD} / \mathrm{BOD}_{5}$ ratio is very important to assess the biodegradability of wastewaters in the treatment plant. During the study period, the values recorded are below 3 and the average value of the $\mathrm{COD} / \mathrm{BOD}_{5}$ ratio is $1.34 \pm 0.14$ (Table 3), which means that the effluents of the great Agadir are easily biodegradable and the dominant character is that of domestic wastewaters.

\section{The $\mathrm{BOD}_{5} / \mathrm{COD}$ ratio}

To characterize industrial pollution, we considered the $\mathrm{BOD}_{5} / \mathrm{COD}$ ratio, which gives very interesting insights into the origin of the wastewater pollution and its treatment options (Benyakhlef et al. 2007).

The values recorded during the study period ranged from 0.69 to 0.90 (Table 3); these values show a very high organic load and confirm the possibility of an easily biological 
treatment, being higher than 0.3 . The $\mathrm{BOD}_{5} / \mathrm{COD}$ ratio indicates a dominance of organic matters (Bouknana et al. 2014).

\section{TSS/BOD 5 ratio}

The average TSS/BOD 5 ratio is $0.51 \pm 0.06$ (Table 3 ), which is relatively low compared to the usual value (between 1.2 and 1.5) (Ministry of Land and of Morocco 2002). This report provides additional information about organic matter quantities in the effluent, but also provides information about sludge production (Mouhanni et al. 2011).

\section{Oxidizable matter}

In wastewater, oxidizable matter is the global assessment of an organic pollution, especially for pollution tax purposes. The term "oxidizable matter" $(\mathrm{OM})$ corresponds to a weighted average of two global parameters the COD and the $\mathrm{BOD}_{5}$, by assigning a double coefficient to $\mathrm{BOD}_{5}$ (Rodier et al. 2009).

In urban effluents, oxidizable materials represent a significant pollutant load and they are taken into account in the definition of the population equivalent. The OM is a

Fig. 2 Fecal coliforms levels in different types of wastewaters in Mzar treatment plant

Fig. 3 Fecal enterococcus levels in different types of wastewaters in Mzar treatment plant
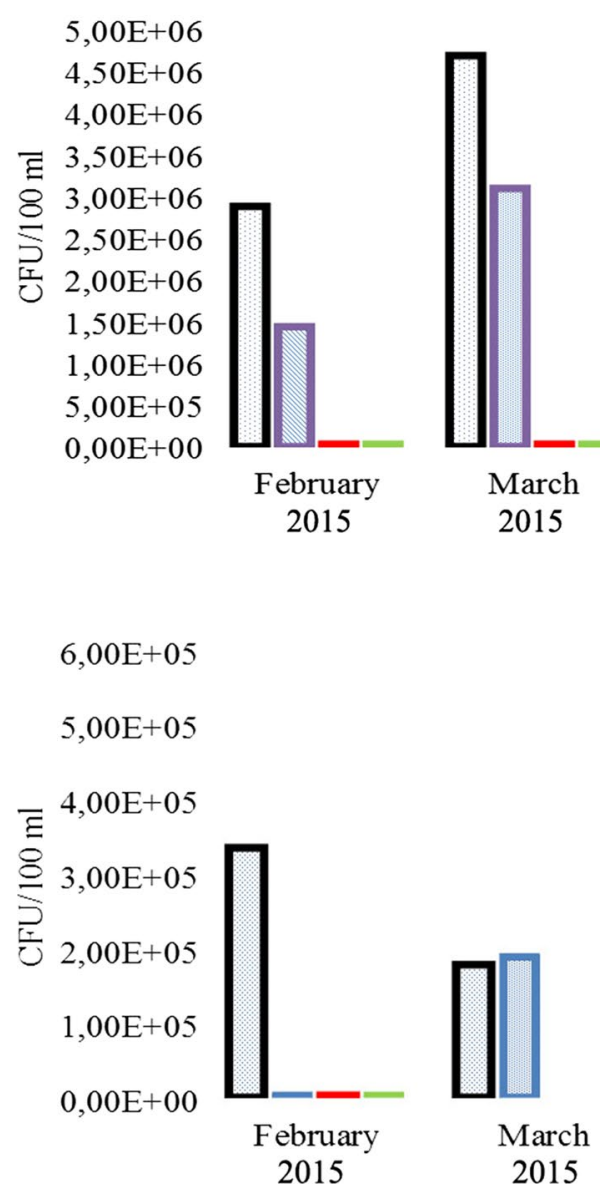
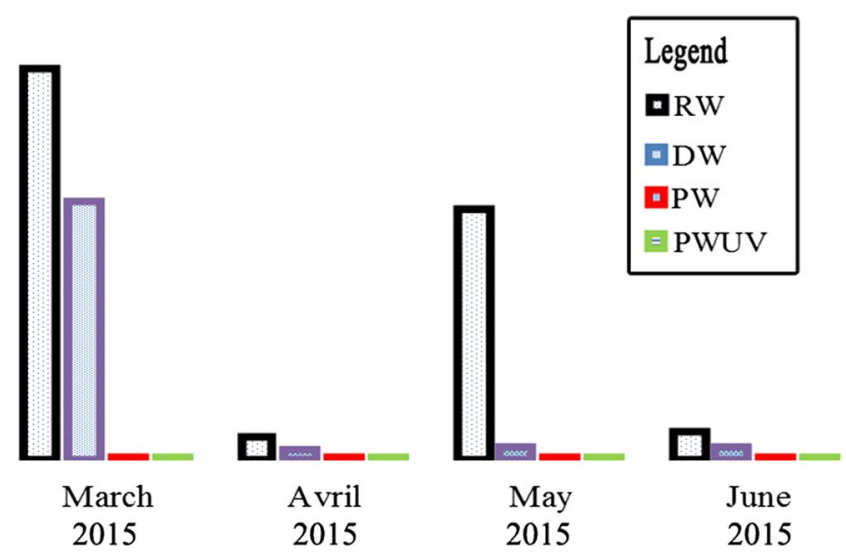

very useful parameter for assessing the pollutant load and possibility of connection of industrial plant to the municipal sewerage network. In reality, most organic materials become polluting only when they are found in excess in the environment (Bouknana et al. 2014).

Through the study period, the values obtained of OM were very high (Table 3); the average value was $1546 \pm 253 \mathrm{mg} / \mathrm{L}$. This result, along with the reports of $\mathrm{TSS} / \mathrm{BOD}_{5}$ and $\mathrm{BOD}_{5} /$ $\mathrm{COD}$, testifies the very high loads of organic matter carried by the effluents of Agadir city.

\section{Enterococcus and fecal coliforms}

The fluctuations of bacterial populations in different sampling points during the study period are shown in Figs. 2 and 3 . The average bacterial loads of fecal coliforms are very high. With $4.71 \times 10^{6} \mathrm{CFU} / 100 \mathrm{~mL}$ in row water, after treatment this value is reduced to $1.45 \times 10^{3} \mathrm{CFU} / 100 \mathrm{~mL}$ in PWUV. However, the loads in PWUV remain above the Moroccans/WHO standard ( $<1000 \mathrm{CFU} / 100 \mathrm{~mL}$ ). Values above the standard were observed during the first 3 months of the study.

It appears that the wastewater treatment process is effective in reducing loads of the enterococcus. During the study

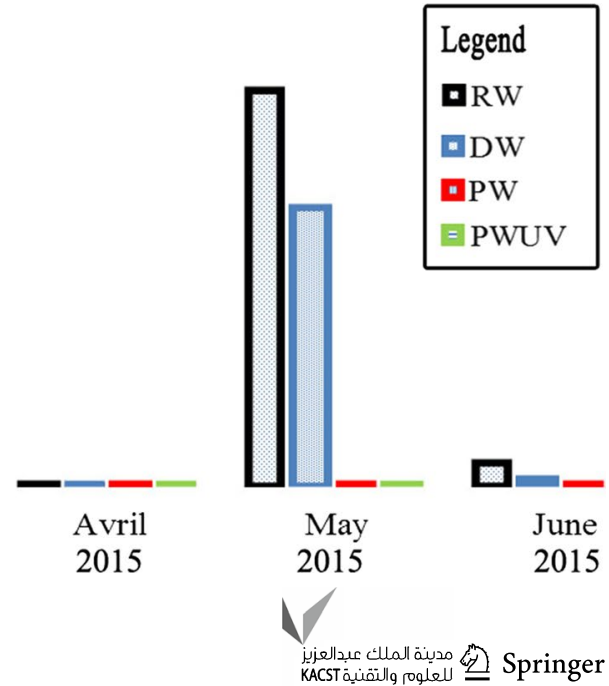


period, high loads of FE were recorded in RW, with an average of $2.62 \times 10^{5} \mathrm{CFU} / 100 \mathrm{~mL}$. These values are reduced gradually as the processing path progresses to reach an average of $7.92 \mathrm{CFU} / 100 \mathrm{~mL}$ in PWUV. Throughout the study period, The $\mathrm{FC} / \mathrm{FE}$ ratio was always superior to three $(\mathrm{FC} /$ $\mathrm{FE}>3$ ), which is an evidence of a human fecal contamination in all types of waters.

\section{Discussion}

The southern Morocco is the most affected by the drought and water scarcity, and available water resources are used mainly in agriculture. Reuse of treated wastewater for watering the city's green spaces seems to be a promising choice to reduce the pressure on the water tables. Currently, the PWUV of the Mzar WWTP are reused to water a golf course in Agadir city. This study aims to evaluate the bacteriological and physicochemical quality of the PWUV, to assess the effectiveness of UV disinfection and to prevent their health and environmental risks.

For studied parameters, the $\mathrm{pH}$ values in different types of waters are close to neutrality and were acceptable for watering green spaces according to de Moroccan standards (MS) similar to the WHO guidelines (Ministry of Land and of Morocco 2002). However, it should be noted that the $\mathrm{pH}$ values which are lower than 5 or higher than 8.5 affect the growth and the survival of soil microorganisms (Jeison et al. 2008).

Through the study period, the temperature in all types of waters was below $35{ }^{\circ} \mathrm{C}$, recognized as the limit value recommended by the MS and WHO. Moreover, the temperature is an important ecological factor for the proper functioning of anaerobic sludge digestion.

The electrical conductivity of the water samples ranged from 2170 to $3340 \mu \mathrm{S} / \mathrm{cm}$. Throughout the study period, higher EC was observed in treated final effluent samples, which reflects a high level of water salinity. The latter increases the osmotic pressure of the soil solution and prevents imbibition of seeds and roots absorption. The increase in electrical conductivity can be explained by: the mineralization of organic matter by bacteria during the treatment process and by the chemical and geometric properties of the sand use in percolation infiltration basins (Et-taleb et al. 2014; El Haouti et al. 2015).

Agadir region is a very active economic and industrial pole. Fisheries are the second important activity of the local population. Every year, the fish plants reject tons of brines and organic matters in sanitation system of the city (Mimouni et al. 2002; Gillet et al. 2003). Consequently, high levels of salinity, $\mathrm{COD}, \mathrm{BOD}_{5}$ and TSS are recorded in raw water. The latter are overloaded by fish scales, which have a very slow biodegradability. Despite the influence of industrial effluents, wastewaters of the greater Agadir remain in the category of readily biodegradable water $\left(\mathrm{COD} / \mathrm{BOD}_{5}\right.$ ratio $<3$ ). In addition, the Mzar treatment plant is able to reduce the $\mathrm{COD}, \mathrm{BOD}_{5}$ and $\mathrm{MES}$ levels below the limit values recommended by the Moroccan and WHO Standards.

Significant work has been undertaken to reduce the discharge of raw industrial wastewater into the city's sewage system, and to encourage industrial wastewater pretreatment. This will have a positive impact on treatment processes. Adequate wastewater treatment can make the slow filtration and the UV disinfection more efficient.

In the field of hygiene and sanitation, bacteriological analyses often involve non-pathogenic microorganisms, but the same germs that not necessarily constitute a risk in itself for public health. Indicators of fecal contamination (IFC) are associated with intestinal pathogens (bacteria and viruses) that are dangerous to human health. In general, these germs act as IFC and allow to assess the risk of contamination by fecal matter that can carry pathogenic microorganisms, or as indicators of treatment effectiveness (ITE), to assess the quality of a water disinfection treatment against pathogenic microorganisms whose presence may be feared in the raw water used (Rodier et al. 2009).

Water disinfection is a treatment that aims to reduce the presence of pathogenic microorganisms in the water. In order to meet the Moroccan standards, the Mzar WWTP uses the UV radiation to disinfect PW. The UV disinfection has many advantages: no by-products formation, short contact time, inactivation of virus and no residues. However, it also has some weaknesses: high energy demand, high cost, influenced by high levels of suspended solids, turbidity and soluble organic matter. The effectiveness of UV radiation disinfection depends on the energy dose absorbed by the organism, the time of exposure, the color and turbidity of water (Farrell et al. 2018). Actually, high loads of TSS can significantly reduce the efficiency of the UV disinfection (Sharrer et al. 2005). If the energy dose is not high enough, the organism's genetic material might only be damaged instead of being destroyed (Collivignarelli et al. 2017). In addition, several studies have reported an increased UV resistance in environmental bacteria and bacterial spores, compared to laboratory-grown strains (Hijnen et al. 2006). Previous studies have proven that some bacteria genus can easily cross the treatment process, while remaining are viable (Eddabra et al. 2011; Fonteneau et al. 2017); and this is further confirmed by the present study.

In treated wastewater, bacterial loads were deeply influenced by the initial loads in raw water, physicochemical parameters and climatic conditions. In fact, slow sand filtration is a water treatment process that is well suited for use by small water systems; the nature of the slow sand filtration causes some serious limitations on utilization of the process. An important limitation is the need for 
high-quality source water or appropriate pretreatment or filter modification to cope with water quality that is less than ideal (Logsdon et al. 2002).

This research showed that the UV disinfection at the Mzar WWTP was insufficient to provide water that meets the Moroccan standards. It would be necessary to combine the UV disinfection with another disinfection process in order to guarantee the safety and salubrity of the PWUV (Li et al. 2018; Sun et al. 2018). Even after treatment, wastewaters constitute a potential risk for human health and environment, and for that reason, it is necessary to keep a constant monitoring. In this study, bacteriological analyses showed significant loads of fecal coliforms. It made us wonder about the effectiveness of Mzar treatment process and the ability of UV reactors to provide waters that meet the Moroccan/WHO standards.

Currently, only one golf course is watered by the PWUV of the Mzar WWTP. Low demand on PWUV can have negative effects on the quality of this water. Indeed, long waiting times and storage conditions may be the cause of cross-contamination. In PWUV storage basins, the bacteriological contamination can be due to bacterial biofilms, accidental contamination and by the multiplication of bacteria that escape the UV disinfection (Farrell et al. 2018).

The climatic conditions play an important role in the treatment process (Chebor et al. 2018), and this becomes more apparent by monthly fluctuations of temperature. Indeed, in the coldest months of the study, significant burdens were recorded, mainly on February and March with the highest FC loads.

In the Mzar treatment plant, it seems that the initial bacterial loads and the temperature were the main factors involved in the bacteriological quality of final effluent. For FE, very low burdens were recorded during the entire study period, with slight increase in the coldest months. In Morocco, there is no standard for the enterococci. However, these organisms were used all over the world to provide additional information on fecal contamination of water (Boehm and Sassoubre 2014). Hence, there is a need for continuous monitoring to assess the effect of seasonal variations on different bacteria loads. Using these waters in green areas irrigation can hinder the quality and safety of these areas and put population at risk. The charges enumerated during the entire period of the study were superior to the Moroccan standards and WHO recommendations. The results obtained during this study corroborate and improve the results obtained previously (Eddabra et al. 2012).

The main limitations of the study were the short duration of this study, no 24/24 direct debiting system and turbidity not being measured, which is a key parameter for UV disinfection.

\section{Conclusion}

Monitoring of the microbiological and physicochemical parameters in all types of waters from Mzar treatment plant made it possible to assess their quality. The following conclusions were drawn from the current study: apart from the high conductivity and high loads of fecal coliforms, all the other parameters were in conformity with the Moroccan standards. Indeed, for fecal coliforms and conductivity, levels recorded during this study were above the Moroccan standard. Unfortunately, PWUVs distinguished for watering green spaces do not meet the criteria set by the Moroccan and WHO reuse standards. Therefore, it is necessary to take appropriate preventive measures in order to reduce the health risk and prevent further pollution of green spaces and groundwater.

As prospects, we plan to study the effectiveness of UV disinfection, to investigate the elimination of same pathogenic bacteria as Salmonella spp. and Vibrio spp. and explore the microbiological impact of PWUV reuse on the groundwater and city's green spaces.

Open Access This article is distributed under the terms of the Creative Commons Attribution 4.0 International License (http://creativeco mmons.org/licenses/by/4.0/), which permits unrestricted use, distribution, and reproduction in any medium, provided you give appropriate credit to the original author(s) and the source, provide a link to the Creative Commons license, and indicate if changes were made.

\section{References}

Aba-aaki R, Ez-zahery M, Et-taleb S et al (2013) Retention of heavy metals $(\mathrm{Pb}, \mathrm{Cd}, \mathrm{Cr}$ and $\mathrm{Zn})$ by a sand area of Agadir: equilibrium and kinetic. In: MATEC web of conferences. EDP Sciences, $p$ 4020

Alla AA, Gillet P, Deutsch B et al (2006) Response of Nereis diversicolor (Polychaeta, Nereidae) populations to reduced wastewater discharge in the polluted estuary of Oued Souss, Bay of Agadir, Morocco. Estuar Coast Shelf Sci 70:633-642

Benyakhlef M, Naji S, Belghyti D (2007) Caractérisation des rejets liquides d'une conserverie de poissons. Bull Soc Pharm Bordeaux 146:225-234

Boehm AB, Sassoubre LM (2014) Enterococci as indicators of environmental fecal contamination. In: Enterococci: from commensals to leading causes of drug resistant infection. Massachusetts Eye and Ear Infirmary

Bouknana D, Hammouti B, Salghi R et al (2014) Physicochemical characterization of olive oil mill wastewaters in the eastern region of Morocco. J Mater Environ Sci 5:1039-1058

Cha W, Choi H, Kim J, Kim IS (2004) Evaluation of wastewater effluents for soil aquifer treatment in South Korea. Water Sci Technol 50:315-322

Chabor J, Mwamburi L, Kiprop E (2018) Use of slow sand filtration technique to improve wastewater effluent for crop irrigation. Microbiol Res 9(1). https://doi.org/10.4081/mr.2018.7269 
Collivignarelli MC, Abbà A, Benigna I et al (2017) Overview of the main disinfection processes for wastewater and drinking water treatment plants. Sustainability 10:86

Eddabra R (2011) Evaluation de la Contamination bacteriologique des eaux usées des stations d'épuration du grand Agadir: isolement, caracterisation moleculaire et antibioresistance des espèces du genre Vibrio. Thèse de doctorat, Ibn Zohr, Strasbourg

Eddabra R, Moussaoui W, Prévost G et al (2011) Occurrence of Vibrio cholerae non-O1 in three wastewater treatment plants in Agadir (Morocco). World J Microbiol Biotechnol 27:1099-1108. https:// doi.org/10.1007/s11274-010-0556-7

Eddabra R, Prévost G, Scheftel J-M (2012) Rapid discrimination of environmental Vibrio by matrix-assisted laser desorption ionization time-of-flight mass spectrometry. Microbiol Res 167:226230. https://doi.org/10.1016/j.micres.2011.09.002

Eddaoudi R, Chafik A, Cheggour A, Moukrim A (2004) Contribution to reassess the health of Agadir Bay after the installation of the wastewater treatment plant: evaluation of metallic contamination. J Mater Environ Sci 5(S1):2278-2283

El Haouti R, Et-taleb S, Abbaz M et al (2015) The use of titaniferous sieved sand for the treatment of domestic wastewater in the percolation infiltration process. Arab J Chem Environ Sci 2(2):58-71

Et-taleb S, Elhaouti R, Abbaz M et al (2014) Comparaison du phénomène de colmatage des eaux usées à travers deux types de sables: l'un vierge et l'autre utilisé lors de traitement par infiltration (Comparison of the clogging phenomenon wastewater through two types of sand: one virgin and one used during treatment with infiltration. J Mater Environ Sci 5(6):1906-1912

Farrell C, Hassard F, Jefferson B et al (2018) Turbidity composition and the relationship with microbial attachment and UV inactivation efficacy. Sci Total Environ 624:638-647

Fatta-kassinos D, Kalavrouziotis IK, Koukoulakis PH, Vasquez MI (2011) Science of the Total Environment The risks associated with wastewater reuse and xenobiotics in the agroecological environment. Sci Total Environ 409:3555-3563. https://doi. org/10.1016/j.scitotenv.2010.03.036

Fonteneau L, Da Silva NJ, Fabre L et al (2017) Multinational outbreak of travel-related Salmonella Chester infections in Europe, summers 2014 and 2015. Eurosurveillance 22:30463. https://doi. org/10.2807/1560-7917.ES.2017.22.7.30463

Gillet P, Gorman E, Tallect P et al (2003) Impacts des rejets urbains sur les communautés benthiques de l'embouchure de l'oued Souss, baie d'Agadir, Maroc. J Rech Ocean 20:39-44

Habbari K, Tifnouti A, Bitton G, Mandil A (2000) Geohelminthic infections associated with raw wastewater reuse for agricultural purposes in Beni-Mellal, Morocco. Parasitol Int 48:249-254. https ://doi.org/10.1016/S1383-5769(99)00026-4

Hijnen WAM, Beerendonk EF, Medema GJ (2006) Inactivation credit of UV radiation for viruses, bacteria and protozoan (oo) cysts in water: a review. Water Res 40:3-22

Jeison D, Kremer B, van Lier JB (2008) Application of membrane enhanced biomass retention to the anaerobic treatment of acidified wastewaters under extreme saline conditions. Sep Purif Technol 64:198-205
Li G-Q, Huo Z-Y, Wu Q-Y et al (2018) Synergistic effect of combined UV-LED and chlorine treatment on Bacillus subtilis spore inactivation. Sci Total Environ 639:1233-1240

Logsdon GS, Kohne R, Abel S, LaBonde S (2002) Slow sand filtration for small water systems. J Environ Eng Sci 1:339-348

Metcalf E, Eddy H (2003) Wastewater engineering: treatment and reuse, 4th edn. Tata McGraw-Hill Publ. Co. Limited, New Delhi, p 1819

Mimouni R, Alla AA, Anajjar EM et al (2002) Impact du rejet des eaux usées sur la qualité microbiologique des plages de la baie d'agadir (Maroc). J Eur d'hydrologie 33:115-123

Mimouni R, Anajjar EM, Finance C, Moukrim A (2003) Distribution des coliformes fécaux dans la Baie d'Agadir (sud-ouest du Maroc). Cah l'ASEES 8:57-60

Ministry of Land W, of Morocco E (2002) Normes marocaines, Official Bulletin of Morocco, No. 5062 du 30 Ramadan 1423, Rabat

Mouhanni H, Bendou A, Er-Raki S (2011) Disinfection of treated wastewater and its reuse in the irrigation of golf grass: the case of plant M'zar Agadir-Morocco. Water 3:1128-1138

Ouhamdouch S, Bahir M, Carreira PM et al (2016) Impact du changement climatique sur la ressource en eau au Maroc; Cas du bassin d'Essaouira. Larhyss J 27:221-237

Qadir M, Wichelns D, Raschid-Sally L et al (2010) The challenges of wastewater irrigation in developing countries. Agric Water Manag 97:561-568. https://doi.org/10.1016/j.agwat.2008.11.004

RAMSA (2002) M'Zar treatment station. In: Water supply serv. Agadir (Régie Auton. Multiservices d'Agadir). http://www.ramsa.ma/ Accueil/EspaceTechnique/Assainissement/Assainissementliquid e/StationdetraitementMZar.aspx. Accessed 2015

Rodier J, Legube B, Merlet N, Brunet R (2009) L'analyse de l'eau-9e éd.: Eaux naturelles, eaux résiduaires, eau de mer (Water Analysis-9th ed: Natural Waters, Waste Waters, Seawater 2009). Dunod

Shakir E, Zahraw Z, Al-Obaidy AHMJ (2017) Environmental and health risks associated with reuse of wastewater for irrigation. Egypt J Pet 26:95-102. https://doi.org/10.1016/j.ejpe.2016.01.003

Sharrer MJ, Summerfelt ST, Bullock GL et al (2005) Inactivation of bacteria using ultraviolet irradiation in a recirculating salmonid culture system. Aquac Eng 33:135-149

Sun P, Zhang T, Mejia-Tickner B et al (2018) Rapid disinfection by peracetic acid combined with UV irradiation. Environ Sci Technol Lett 5(6):400-404. https://doi.org/10.1021/acs.estlett.8b00249

Touyer O, Zekhnini A, Rondelaud D, Moukrim A (1998) Incidence des helminthoses intestinales chez les enfants vivant dans la zone d'épandage des eaux usées d'Aghroud, agglomération d'Agadir (Sud du Maroc). Bull la Société française Parasitol 16:298-304

Publisher's Note Springer Nature remains neutral with regard to jurisdictional claims in published maps and institutional affiliations. 